\title{
Sejarah Pemikiran Ekonomi Islam
}

Dalam sejarah peradaban yang sangat panjang, Segala bentuk Pemikiran melahirkan konsep, gagasan dan teori dalam sebuah sistem atau ilmu ekonomi. Salah satu sistem ekonomi yang dalam perkembangannya yang cukup pesat melainkan Kapitalisme dan Sosialisme adalah Ekonomi Islam. Ekonomi Islam Hadir untuk mengkritisi Kapitalis dan Sosialis yang selama berpuluh abad tidak mampu menyelesaikan segala persoalan yang ada. Ekonomi Islam pun tidak hanya sekedar opsi, tetapi juga solusi yang patut di syukuri.

Ekonomi islam dalam perkembangannya tidak terlepas dari peran para pemikir-pemikir muslim yang selalu melakukan pengkajian, pembaharuan, dan ijtihad. Sejarah Pemikiran Ekonomi Islam pun di klasifikasikan menjadi 3 Fase yaitu Fase klasik di era Rasulullah saw dan khulafaurrasyidin, kemudian Fase kedua di sebut fase transisi atau stagnasi di era Dinastidinasti, dan terakhir di fase kontemporer yang berkembang pesat hingga saat ini. Namun, jika melihat siklus sejarah pemikiran ekonomi islam, dapat di bagi kedalam 7 siklus yaitu pada masa Rasulullah, khulafaurrasyidin, dinasti, mercantilisme, kapitalis, sosialis, dan kontemporer.

Berbeda dengan Peter Gran, Ia mengklasifikasikan pertumbuhan perjalanan ekonomi pemikiran Islam menjadi 5 sesi. Sesi awal, dikenal dengan“ masa jahiliyah” yang berakhir sampai tahun 660 Masehi, yang mana bentuk perekonomian masih mayoritas corak nomadis. Sesi kedua, pada 660- 950 dikenal dengan masa negara yang memberikan upeti, dimana warga pada biasanya bergeser melalui kehidupan nomaden menuju bercocok tanam. Sesi ketiga, kurang lebih pada tahun 950- 1550 dikenal dengan masa negara pedagang yang memberi upeti sebab kegiatan perekonomian pada masa tersebut didominasi dari kegiatan perdagangan. Sesi keempat, mulai tahun 1550 sampai dengan1850 merupakan sesi formasi aktivitas kerajaan pinggiran dengan corak yang kecenderungan warga buat meninggalkan metode hidup seperti koloni kecil serta membuat koloni menjadi lebih besar dengan wujud kerajaan. Serta sesi kelima, mulai tahun 1850 sampai saat ini dikenal dengan sebutan masa kapitalisme pinggiran. (Sirajuddin, 2016)

Jika mengacu pada sejarah, Fase I Pemikiran para Ekonom Robbani dimulai semenjak Muhammad SAW diakui menjadi seorang Rasul. Rasululah SAW menghasilkan beberapa kebijkan menyangkut bermacam perihal berkaitan dengan permasalahan kemasyarakatan, tidak hanya permasalahan fiqih, maupun politik( siyasah), pula permasalahan perniagaan ataupun 
ekonomi (muamalah). Masalah ekonomi para umat jadi atensi Rasulullah SAW, sebab permasalahan ekonomi ialah pondasi keimanan yang wajib dicermati. Setelah itu, kemudian kebijakan baginda Rasulullah SAW menciptakan pedoman untuk para Khalifah selaku penggantinya dalam hal memutuskan permasalahn ekonomi.(Bin et al., 2020)

Fase selanjutnya yang dikenal dengan Fase II atau masa yang cemerlang namun juga mengalami kemunduran, karenanya di sebut masa Transisi dan Stagnasi yang mewarisi banyak peninggalan intelektual yang sudah disusun jadi konsep yang dapat diaplikasikan dalam aktivitas ekonomi warga yang berlandaskan syariat yaitu Al- qur' an serta hadist. Walaupun di lain sisi, cendekiawan pada era ini menghadapi kenyataan politik yang lumayan susah. Dimana terjalin perpecahan puncak kekuasaan yang kebanyakan mengabaikan kemauan masyarakat. Serta mulai meruasnya korupsi di golongan penguasa yang menimbulkan ketimpangan sosial terus menjadi lebar. Tokoh pemikir pada era ini antara lain: Abu Yusuf, Al- Ghazali( 505 H/ 1111 Masehi), Abu Hanifah, Ibnu Taimiyah( 728 H/ 1328 Masehi), Al- Syatibi( 790 H/ 1388 Masehi), Ibnu Khaldun( 808 H/ 1404 Masehi) serta Al- Maqrizi( 845 H/ 1441 Masehi).(Istiqomah et al., 2019)

Fase III yaitu fase Kontemporer yang dimana pemikir pemikir muslim sudah bermunculan kembali dan menghasilkan beberapa mazhab. secara garis besar digolongkan menjadi tiga corak: Madzhab Baqir as Sadr, Mainstream dan Alternatif Kritis.

1. Madzhab Iqtishoduna yang di pelopori Baqir As Sadr, melaporkan jika ada perbandingan yang sangat mendasar antara ilmu ekonomi dengan ekonomi Islam. Dilatarbelakangi oleh ketidksetujuannya dengan konsep dan definisi dari ilmu ekonomi yang menyangka kalau permasalahan ekonomi timbul akibat sumber energi ekonomi yang langka sedangkan kemauan manusia yang tidak terbatas. Sebagian ahli yang setuju dengan madzhab ini antara lain: Ali Syariati, Baqir As Sadr, Kadim As Sadr, Abbas Mirakhor.

2. Madzhab Mainstream, mempunyai pandangan bahwa perbedaan mendasar diantara ilmu ekonomi Islam dan ilmu ekonomi konvensional ialah dalam hal pencapaian tujuan. Yang mana ekonomi Islam tetap berpandangan kritis terhadap aspek normative, madzhab mainstream focus pada cara pengelolaan sumber energy/daya yang terbatas dan keinginan manusia yang tidak ada batasnya dengan cara yang adil dan semestinya sesuai al-qur'an, hadist dan praktik ekonomi 
Islam pada masa kejayaannya. Para Pemikir dari Mazhab ini Ialah: Khursyid Ahmad, Najetullah Siddiqi, Umar Chapra, Afzalurahman, Muhammad Abdul Manan, Monzer Khaf, dsb.

3. Madzhab Alternative Kritis, adalah mazhab dari beberapa kelompok yang mengundang umat Islam untuk bersikap kritis tidak hanya terhadap semua sistem seperti kapitalisme, sosialisme, namun juga terhadap sistem ekonomi Islam. Pandangan menurut mazhab ini adalah bahwa Islam sudah pasti benar namun ekonomi Islam belum tentu benar, dikarenakan Ekonomi Islam adalah hasil tafsiran manusia walaupun berpedoman kepada al-qur'an dan hadist. Maka menurut mazhab ini, statement di dalam ekonomi Islam masih perlu di gali benar salahnya agar kemudian dapat dibuktikan secara ilmiah. Beberapa tokoh yang menganut mazhab ini antara lain: Timur Kuran, Prof. Jomo dan Prof Muhammad Arif.(Istiqomah et al., 2019)

Walau berbeda pandangan, ketiga mazhab diatas tidak pernah keluar dari koridor islam yang berlandaskan alquran dan hadist. Perbedaan pandangan diantara berbagai mazhab bukan berarti melemahkan ekonomi islam. Justru perbedaan tersebut memperkaya khazanah keilmuan ekonomi islam. Tak dapat di pungkiri bahwa Ekonomi Islam pernah mengalami masa Kemajuan dan Stagnasi. Namun, jika berkaca pada realitas Sistem yang ada baik itu kapitalis maupun sosialis, ternyata tidak menjawab permasalah sosio ekonomi yang ada. Karenanya, para pemikir ekonomi islam kembali bercermin pada warisan agama islam yang nyatanya dapat memberikan solusi, bukan hanya sekedar opsi.

\section{Daftar Pustaka}

Bin, Z., Dan, A. L. I., Hanifah, A. B. U., Liri, Y., Muhammad, W., \& Ha, R. (2020). Pemikiran Ekonomi Islam Pada Fase Pertama ( Zyad Bin Ali dan Abu Hanifah ) Yustiasari Liri Wati*

2) Muhammad Rafai HA* 1) STAI Auliaurrasyddin Tembilahan 2) STAI Ahsanta Jambi. Al-Muqayyad, 3(1), 106-113.

Istiqomah, L., Islam, P. E., \& Global, E. (2019). Jurnal Al-Iqtishod Jurnal Al-Iqtishod. AlIqtishod, 1(1), 1-19.

Sirajuddin. (2016). Konsep Pemikiran Ekonomi Islam. Laa Maysir, 3(1), 46-60.

Penulis : Ainan Radiyah

Nim : 90100118016 